\title{
ROLE OF HANDICRAFT SECTOR IN THE ECONOMIC DEVELOPMENT OF UTTAR PRADESH
}

Dr. Anoop Kumar Singh ${ }^{* 1}$, Ms. Sumbul Fatima ${ }^{2}$

*1 Assistant Professor, Department of Applied Economics, University of Lucknow, INDIA

${ }^{2}$ Research Scholar, Department of Applied Economics, University of Lucknow, INDIA *Correspondence Author: shamsi25s@gmail.com

\section{Abstract:}

Handicraft Sector is one of the emerging sectors playing a very important role in the economic development of Uttar Pradesh. The country full of colors has great opportunities in the economic growth and development as each and every one has the capacity as well as the capability to do something creative by his or her inherent talent. India is also known for its great contribution towards exports from the handicraft sector towards the foreign world. The growth potential of U.P. is that it is one of the fastest developing states in India and how handicraft sector possesses opportunities which can help in the economic development of the state and therefore it requires a great amount of support from the government to be fully equipped and developed. Since this sector is labour intensive, it gives a great deal of employment opportunities as well as key to further enhancement of living standard and thus bringing in more positive impact on economic development of the state. In order to boost up the exports of handicrafts from U.P. the government has set up special economic zones. Therefore this paper is an attempt to look into the emerging opportunities for growth through this sector in Uttar Pradesh and what measures could be taken upon so as to tap the untapped growth in the sector.

Keywords:

handicraft sector, economic zones, untapped growth, artistic, tourism, employment.

Cite This Article: Dr. Anoop Kumar Singh, and Ms. Sumbul Fatima, "Role of Handicraft Sector in The Economic Development of Uttar Pradesh." International Journal of Research Granthaalayah, Vol. 3, No. 1(2015): 58-64. DOI: 10.29121/granthaalayah.v3.i1.2015.3054.

\section{INTRODUCTION}

Handicraft products or items are those which are produced either out of the use of hands or with the help of some kind of tool. It is such an art form which requires more of manual work and less amount of machinery. In a layman language, as soon as the word handicraft comes, it is the skill that is solely an individuals' own work giving it more value not in terms of money but in terms of the amount of energy, mental strength and use of hands. It is dependent more on the amount of contribution of the person who has made the raw material take the shape of a final product with little or sometimes no use of tool or machinery. Such art forms have been in tradition since years and the need are to make them revive, relived in such a way so that they remain alive in many more generations to come. 


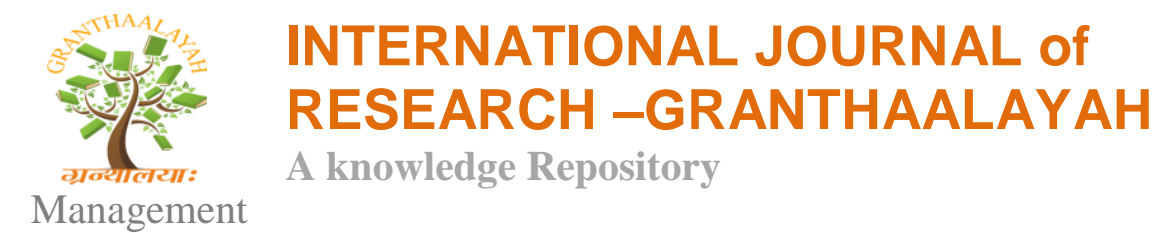

Such products can be utilitarian, aesthetic, artistic, creative, culturally attached, decorative, functional, traditional, religiously and socially symbolic and significant. Handicraft is such that although the item might be same in appearance but since produced in a different region from different hands differ in style, color, combination and craftsmanship.

Some of the professors of Ross School of Business, University of Michigan, Prof. C. K. Prahalad, Paul \& Ruth McCracken said, "India needs to focus on the flowering of arts, science, and literature. The goal is to see India become the world's benchmark on how to cope with diversity. It can become a benchmark for the practice of universality and inclusiveness. Inclusive growth is not about subsidies. It is about creating sustainable opportunities." It is deduced from the above statement that in order to make a mark with inclusive growth then the government need to work upon not only on the organized sector but it also need to bring its concentration on the unorganized sector where the huge number of small scale industries specially the handicraft industry are struggling to make a suitable and dignified identity for themselves.

\section{OBJECTIVE OF STUDY}

To analyze the role of handicraft sector in Uttar Pradesh.

To examine the emerging opportunities for growth through handicraft sector in Uttar Pradesh.

To provide valuable suggestions to enhance the promotion of Uttar Pradesh handicraft sector.

\section{RESEARCH METHODOLOGY}

The present study is theoretical in nature. The scope of the study extends to the handicraft sector of India where a case of Uttar Pradesh State has been taken into consideration. The major motive behind the present study is the eminent prospects of Uttar Pradesh handicraft sector in contributing towards economic development of the state and the nation as a whole. The data for the present study has been collected from secondary sources. The data analysis has been done through secondary review and content analysis has been performed to arrive at conclusions and discussion. The secondary sources of the data includes books, journals, newspapers, published and unpublished research work, various search engines, etc. The up to date quantitative data has been collected from the official websites of the Indian handicraft industry as well as U.P. handicrafts.

\section{HANDICRAFT SECTOR IN INDIA: AN OVERVIEW}

India is one of the most diversified countries in terms of culture, heritage, traditions and values. The handicraft items in India has a long dated history due to which India has emerged as one of the major supplier of handicraft products. The handicraft skill lies at every corner of the country if explored thoroughly be it rural or urban sector. The only problem which lies in this sector is the problem of being unorganized and also unrecognized to the fullest. For some of the rural areas, handicraft is the only source and major source of income. Mainly this sector is decentralized and many of the manufacturing units are located in rural areas and small towns and where there is huge involvement of women who has to feed the family in each and every way. 


\section{INTERNATIONAL JOURNAL of RESEARCH -GRANTHAALAYAH

Some of the major centres of handicraft products in the country are Rajasthan famous for its 'Jaipuri Quilts', 'Bagru and Sanganer printed Textiles' and 'wooden and wrought iron furniture from Jodhpur'. Going downward towards the coastal side is the state of Gujarat famous for 'embroidered articles from Kutch', then there are 'Lace and lace goods from Naraspur' in Andhra Pradesh and in the northern region there is Uttar Pradesh which is famous for its 'Brass products from Moradabad' also known as 'Peetalnagri', 'Wooden products from Saharanpur', Firozabad for Glass products'. Henceforth, India has lot to offer beside these.

\section{HANDICRAFT SECTOR IN UTTAR PRADESH}

Uttar Pradesh is the most populated state of the country with a total population of 200 million as per census of 2011 that comprises $16.5 \%$ of the total Indian population. It is not only abundant population wise but also imbibed with varied culture, religion and multiplicity in geographical land. As per the report of FICCI India Central Europe Business Forum, Uttar Pradesh is the fifth largest state with $7.3 \%$ area in size as well as third largest economy with $8 \%$ GSDP, of the country. It holds the first rank in potato production, livestock excluding cow and milk production contributing $34 \%, 11 \%$ and $17 \%$ respectively. The state has also accredited with great amount of minerals, forests, flora and fauna. U.P. is also renowned for its architectures and rich art and craft work.

The major treasures of handicraft items in U.P. are Moradabad and Aligarh for Brassware, Saharanpur for Woodcraft, Kanpur and Agra for Leather goods, Agra again for Marble craft and Stoneware, Bhadohi-Mirazapur, Agra and Hathras for Floor coverings, Glassware from Firozabad, Chikankari from Lucknow, Appliqué work from Rampur and many more cities with unknown treasure of craftwork. Major clusters in the state are listed below:

\begin{tabular}{|l|l|}
\hline LOCATION & PRODUCTS \\
\hline Bulandshahr & Ceramics \\
\hline Moradabad & Brass \& Art ware, Metal ware \\
\hline Bhadohi, Varanasi, Mirzapur, Shahjahanpur & Carpet \\
\hline Lucknow and nearby districts & Chikan \\
\hline Khurja, Nizamabad & Pottery \\
\hline Saharanpur & Woodcarving \\
\hline Aligarh & Locks, Building Hardware, Artmetal \\
\hline Varanasi & Silk and Brocade, Benarsi saree \\
\hline Kanpur, Unnao, Agra & Leather \\
\hline Jhansi, Mau & Powerloom, Handloom \\
\hline Lucknow, Farukhabad, Bareilly, Unnao & Zari, Embroidery \\
\hline Meerut, Kanpur, Varanasi, Ghaziabad & Art Jewellery \\
\hline Meerut & Scissor \\
\hline Firozabad & Glass \\
\hline Noida & IT/ITeS \\
\hline
\end{tabular}




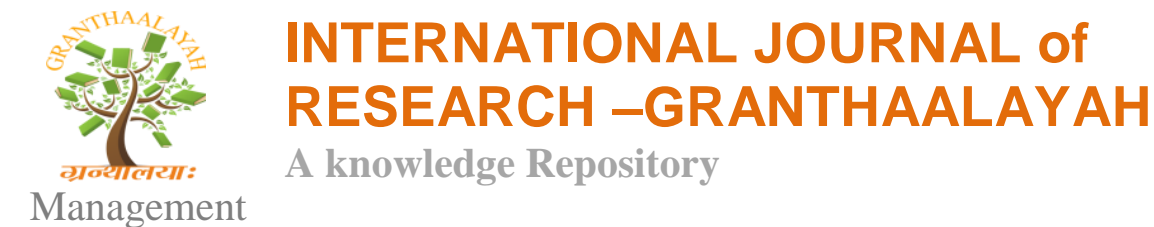

Source: Annual plan 2012-13, Government of U.P., Udyog Bandhu, FICCI India Central Europe Business Forum

Many large scales as well as small scale industries are located in Uttar Pradesh forming an important segment in the state. Recently it has been stated that MSME (Micro, Small and Medium Enterprises) is the life blood of U.P.'s industrial economy. MSME sector has emerged as one of the most potential sector in terms of growth and development with great opportunity of employment, export, foreign exchange earnings, rural upliftment, reducing regional imbalances and last but not the least equitable distribution of national income and wealth. The state has 44.03 lakh enterprises (including both registered and unregistered), which has simultaneously provided employment to 92.36 lakh people (both in registered and unregistered enterprises)and has been the leading state both in terms of enterprises and employment.

\section{EMERGING OPPORTUNITIES FOR ECONOMIC DEVELOPMENT THROUGH HANDICRAFT SECTOR}

Some of the regions where handicraft sector has great opportunities for growth and where it could be further promoted and boosted are as follows:

\section{TOURISM}

Why 'Taj Mahal' one of the Seven Wonders of the World is the most sought after destination for national and international tourists which is located in the city of Agra in Uttar Pradesh is because of its unique and intricate craftwork on the whole structure towards which people are attracted and they come to see the unbeatable beauty. Similarly the handicraft work hold specialty for its unique features which can play an important role in the economic development of the state through tourism. Various markets can be introduced at these places to provide a platform to artisans to showcase their hidden talent which can attract the tourists and foreign currency could be flown in.. The government can also introduce information cell in order to create awareness for these handicraft work. Since the state has vibrant handicraft culture, a handicraft circuit has been introduced for new tourism infrastructure which might take place in Lucknow, Agra, Aligarh and Firozabad. The state has also enormous resources for wildlife, cultural, adventure and Pilgrimage tourism. The prominent tourist and historical destinations are Varanasi, Piprahwa, Kaushambi, Shravasti, Kushi Nagar, Agra, Lucknow, Chitrakoot, Jhansi, Allahabad, Vrindavan and Meerut. Therefore a proper network can well be created for handicraft workers at these tourist places.

\section{EMPLOYMENT}

There is a direct relationship between employment in handicraft and economic development of the state. As it a labour intensive sector with great potential of employment opportunities both in the rural as well as urban areas. The importance of this sector lies in it requiring low capital investment, high value addition, and negotiable import content and high potential for export earnings. Since this sector is equipped with these features, employment opportunities could well be created through establishment of organized handicraft centers and channelizing the already working units so that proper wage rates plus incentives could be maintained and more employment could be 


\section{INTERNATIONAL JOURNAL of RESEARCH -GRANTHAALAYAH

provided. According to NCAER (National Council of Applied Economic Research) U.P holds $29 \%$ of the total Indian artisans as stated in the Development Report of U.P. One of the highest employing craft in the state was the Carpet weaving which employed around 1125000 workers as against the total carpet weavers in the country as estimated during tenth plan period. It was also estimated that employment could reach 80 lakhs by the end of eleventh plan. This Indian knotted carpet industry estimated to employ about 15 lakhs weavers.

\section{EXPORT}

Exports' being the essential constituent in the economic development of the state, the export of handicraft items from the state also plays a significant role, inviting foreign investments and earning foreign exchange. The state comprises of about $60 \%$ of the total export from the handicraft sector. For this, the state had set up Export Promotion Bureau in 1999 to facilitate exports from the state. Major export products from the state are marble products, art pieces, bags, gems and jewellery, apparel, electronics, computer, hardware, software, leather, silk carpets, etc. The prominent export zones in the state are Noida, Agra, Moradabad, Lucknow, Kanpur, Varanasi, Jhansi and Lalitpur. The state has set up Export Promotion Industrial parks at Greater Noida and Agra. Uttar Pradesh has also set up NOIDA SEZ and Moradabad SEZ to facilitate and boost the exports of gem and jewellery and electronics software respectively. The first three prominent craft products in terms of export are from the state of U.P. which includes hand-knotted carpets, art metal ware, and wood ware. India is the third largest supplier of carpets to the world market. In order to enhance the productivity, various training programmes have been developed by the state for up skilling the artisans. As per Udyog Bandhu, FICCI India Central Europe Business Forum, the trend in handicraft export in U.P. has been rising from 10.17 to 10.42 to further 10.78 in financial year 2011, 2012 and 2013 respectively, all estimated in USD'00mn. With this, one can boost up the export of handicraft items through proper marketing plus increasing the production level of these exported items.

Hence, in order to promote handicraft sector in U.P., the state government seeing the role of this sector has taken the initiative to introduce U.P. Handicraft Promotion Scheme for improving the status of handicraft artisans, this scheme also promised to increase the share of handicraft products in exports as reported in one of the leading newspapers. Therefore below are some recommendations for tapping the untapped handicraft sector and recognizing its importance at national and international level.

\section{RECOMMENDATIONS}

The following recommendations might bring an increase in the growth of handicraft sector in the state of Uttar Pradesh:

- To identify the areas having demand for the handicraft products.

- To create demand for the handicraft products through proper sales and promotion activities. 


\section{INTERNATIONAL JOURNAL of RESEARCH -GRANTHAALAYAH \\ A knowledge Repository}

Management

- To provide better market for the handicraft products through arrangement of exhibitions trade fairs, trade shows, event management programs at district, national and international level at regular intervals.

- To organize trade fairs and exhibitions at places where concentration of tourist is found more so that cross-cultural interaction takes place.

- To upgrade the existing strategies to minimize the cost and maximize the profit.

- To involve more of labourers in the production units which could help increase the output as well as standard of living may also increase.

- To run more training programs for the up gradation of skilled, semi-skilled and unskilled workers and to provide better working environment to enhance the production level.

- To provide better remuneration for the work as well as provide incentives to motivate the workers and uniformity should be maintained for the same amount of work.

- To bring in such technologies with which workers may increase the productivity levels and to make the workers aware of such technologies and provide them hands-on-training.

- To bring in Cost Effective Distribution Development using both Physical and Electronic Distribution Channel (Internet, e-Commerce)

- Focus should be on brand promotion of the U.P. handicrafts, product development, assessment and survey of customer preferences, fashion trends at regular intervals.

- Government should develop investment strategies to attract foreign players especially in this sector.

\section{CONCLUSION}

Seeing the overall scenario and performance of the state in the handicraft products, it is indeed a pride for the state which has been able to maintain growth and development in the sector especially in terms of export. Since there is a huge demand for the handicraft products from India and when U.P. has lot to offer in this sector, it is required to integrate this sector with other sectors and markets to tap the emerging opportunities for economic growth from this sector. Although U.P. might be the leading exporter in hand-knotted carpets but the other products which are still not being explored to the fullest, it is needed to throw attention on their growth. It is required to employ workers for the whole of the year rather than for just a small period so that stability is maintained in employment levels. The unorganized market need to be organized and proper platform be provided for assimilation of market information system.

\section{REFERENCES}

[1] Khan, W.A, and Amir, Z. Study of Handicraft Marketing Strategies of Artisans in

[2] Uttar Pradesh and Its Implications, Research Journal of Management Sciences, Vol. 2(2), Feb. 2013.

[3] Dar, M.A. and Parrey, A.H. Socio-Economic Potential Of Handicraft Industry In Jammu and Kashmir: Opportunities And Challenges, International Monthly Refereed Journal of Research In Management \& Technology, Vol. II, July 2013. 


\section{INTERNATIONAL JOURNAL of RESEARCH -GRANTHAALAYAH \\ A knowledge Repository}

[4] Jadhav, S.,Indian Handicrafts: Growing or Depleting?, IOSR Journal of Business and Management (IOSR-JBM).

[5] Mathew, P.M. Employment in Handloom and Handicrafts Sectors, Yojana, May 2011.

[6] Sharma, V. and Yadav, S. Rural Cottage and Handicraft Industries In India "Challenges and Opportunities", TMIMT.

[7] Hashmi, S.K. Market for Indian Handicrafts, Excel Journal of Engineering Technology and Management Science, Vol. I No.1, December-January 2012.

[8] Uttar Pradesh New Vistas for Growth \& Partnership, FICCI India Central Europe Business Forum.

[9] Uttar Pradesh: The State Profile, PHD Chamber of Commerce and Industry, December2011.

[10] Uttar Pradesh Development Report, Planning Commission, Government of India.

[11] Uttar Pradesh Annual Report 2010-11.

[12] Development of Handicrafts in India, Handbook of Statistics and Indian Economy, Reserve Bank of India, Bombay, 2006, p. no. 131-132.

[13] Indian Handicrafts Industry.

[14] Annual Report MSME 2012-13.

[15] Census 2011.

[16]The Times of India, October 17, 2014, 10.41PM 